$\begin{array}{lllll}\text { 大西 基代* } & \text { 戸田 静男 菅田 良仁 } \\ \text { 東家 一 雄 黒岩 共一 } & \text { 木村 通 郎 }\end{array}$

要旨 隔物炎は, その温熱刺激と隔物の作用を生体に与之, 治療効果 を得ていると考えられている。そこで，隔物の炎により溶出する含有 成分の検出を thin layer chromatography を用いて行った。その結果, 隔物として用いた生姜，大蒜より各々の含有成分の溶出が確認された。 このことは, 隔物から溶出する成分の薬理作用が, 温熱刺激とともに 重要な役割を持つことを示唆している。

\section{I 緒言}

尒療法の一つである隔物炎は，古来より腫れ物 などの治療によく用いられているが, 隔物の薬理 作用を利用した適応がなされていることが多い1)。 炎の熱により隔物から含有成分が溶出し，薬効を 発現していると思われる。そこで今回, 生姜, 大 蒜を隔物として用い溶出する成分の検出を行った。

\section{II 方法}

隔物としては，生姜，大蒜を用いた。生姜尒で は, 生姜の含有成分である 6-gingeol, 大蒜尒では, 大蒜の含有成分である allicinの検出を thin layer chromatography（TLCと略す）を用いて行った。

1 ) メタノールエキスの調整

小嶋らの方法 ${ }^{2)}$ を参考にして, 図1のように蒸発皿 上に $0.5 \mathrm{~cm}$ にスライスした生姜片，大蒜片を置き， その上に温尒艾 $0.75 \mathrm{~g}$ を乗せ点火燃焼させた。 4 壮 後メタノールで蒸発血を洗い出しろ過, ろ液をエ バポレートし各々メタノールエキスとした。

* Motoyo OHNISHI 関西銊尒短期大学

共同研究者: Shizuo TodA, Ryojin SugATA, Kazuo ToHYA, Kyoichi KuroIWA, Michio KIMURA 関西鍼炎短期大 学

Key Words：隔物炎, 生姜, 大蒜
2 ）生姜炎のメタノールエキスのTLC

生姜尒のメタノールエキスは，第11日本薬局方 の生薬の確認試験法 ${ }^{3)}$ に基づき TLCを行った。展 開溶媒は，四塩化炭素ーアセトン $(5: 1)$ 。呈色試 薬としてバニリン一硫酸一エタノール試液を均等 に噴霧し加熱発色させスポットの確認をした。

3 ）大蒜尒のメタノールエキスのTLC

大蒜尒のメタノールエキスは，allicinを対照と してTLCを行った。展開溶媒は, へキサンー酷酸 エチル $(10: 3)$ 。呈色試薬として $50 \%$ 硫酸を均等に 噴霧，加熱発色させスポットの確認をした。

生姜炎, 大蒜尒共に TLC プレートとして precoated silica gel 60 plate (Merck, 厚さ $0.25 \mathrm{~mm}$ ) をもちいた。

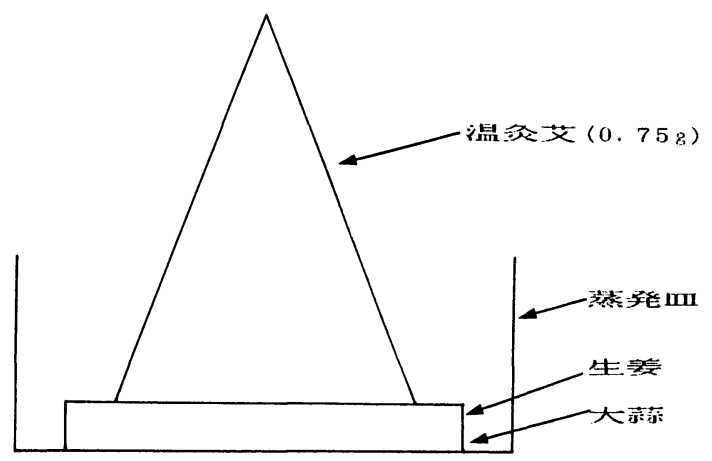

図 1 施炎方法 


\section{III 結 果}

\section{1 ）生姜炎の TLC}

生姜尒の TLCの結果を図 2 に示す。 $\mathrm{Rf}=0.7$ に 紫色のスポットが認められた。これは，第11日本 薬局方により 6-gingeolのスポットであることが示 唆された。 $\mathrm{Rf}=0.15 ， 0.37$ ，にもスポットが認め られた。

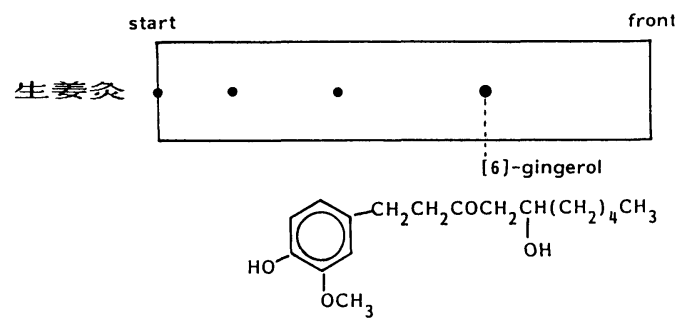

図2 生姜炎のメタノールエキスの thin layer chromatograph

\section{2 ）大蒜尒の TLC}

大蒜尒と allicinのTLCの結果を図 3 に示す。 $\mathrm{Rf}=0.81$ に対照の allicin と同一のスポットである ことが示唆された。 $\mathrm{Rf}=0.27,0.39,0.44$ ，にも スポットが認められた。

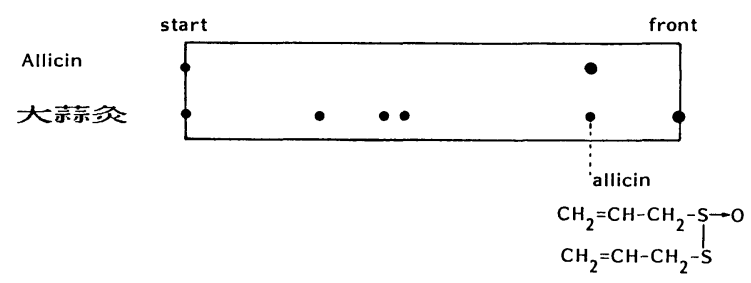

図3 大蒜炎のメタノールエキスの thin layer chromatograph

\section{IV 考察}

図 2，3のよjに生姜炎，大蒜尒共に施炎によ り含有成分の溶出が確認された。又，幾つかのス ポットが認められたことより, 他の成分の溶出も 示唆された。

生姜炎は，腹痛，泄瀉，関節の酸痛などの治療 によく用いられ ${ }^{4)}$,生姜の辛味成分の 6-gingeol の
薬理作用である鎮痛作用 ${ }^{2)}$ を利用した適応がなされ ている。大蒜尒は，癰疽，打撲，動物の咬傷，肺 結核の治療に用いられ $れ^{5,6)}$ ，大蒜の含有成分である allinが酵素によって分解されて生ずる allicinの 強い抗菌，抗真菌作用 ${ }^{7)}$ 利用した適応がなされて いる。

温熱効果における生姜尒と大根尒との比較では, 差が見られなかった ${ }^{2)}$ ことらも，隔物の役割は， 艾の燃焼温度の緩和だけでなく隔物成分の薬理作 用が重要な役割を持つと思われる。

溶出した成分の定量や他の成分についてもさら に検討していく必要があると思われる。

\section{参考文献}

1）大西基代ほか：名家炎選における隔物炎につい $\tau$ ，全日本鍼炎学会第37回学術大会子稿集, 105. (1987)

2）小嶋文夫ほか：隔物尒の温度特性(第 2 報)，東 洋療法学校協会学会誌 9;29. (1985)

3）第11改正日本薬局方，廣川書店，D-451. (1986)

4）井垣清明ほか：針尒学, 刊々堂, 445. (1983)

5）木下晴都：針尒学原論，医道の日本，182. (1983)

6）国分壮識：最新鍼尒医学, 医歯薬出版, 231. (1956)

7）難波恒雄：原色和漢薬図鑑，保育社，241. (1980)

(テ590-04 大阪府泉南郡熊取町小垣内 990 関西鍼炎短期大学) 


\title{
Research on indirect moxibustion
}

\author{
Motoyo Ohnishi, Shizuo Toda, Ryojin Sugata, Kazuo Tohya, \\ Kyoichi Kuroiwa and Michio Kimura \\ Kansai College of Acupuncture Medicine
}

\section{Summary}

Indirect moxibustion has been found to have the effects of thermal stimulation and pharmacological effects as we analyzed the intercalated substance with thin layer chromatography, 6-gingeol from zingiberis Rhizoma and allicin from Allis Bulbus were detected.

It is suggested that pharmacological effects of intercalated substance were significant in indirect moxibustion. 